\title{
KÜLÖNBÖZŐ ÉTRENDEK, DIÉTÁK HATÁSA A SPORTTELJESÍTMÉNYRE
}

\author{
Sarang Zsolt, Gyenes Dominik \\ 1Biokémiai és Molekuláris Biológiai Intézet, Általános Orvostudományi Kar, Debreceni Egyetem
}

\section{Összefoglaló}

Az emberi test üzemanyaga a táplálék, pontosabban az abban található tápanyagok, ezért még a nem sportolóknak is kiemelt figyelmet kell fordítani arra, mi az, amit megesznek. A sportolóknak ennél is fontosabb, hogy kialakítsák a teljesítményt optimalizáló táplálkozási szokásokat. A teljesítményoptimalizálásnak a sporttáplálkozás az egyik legnagyobb, az utóbbi időben egyre jobban elötérbe kerülő lehetősége. Számos speciális étrend létezik, ezek közül talán a legismertebbek: ketogén diéta, mediterrán étrend, vegetarianizmus, paleo diéta. Étrendünket úgy kell megválasztanunk, hogy közben az egészségmegörzés is fontos szempont maradjon. Nem szabad megfeledkeznünk arról, hogy egészen más tápanyagszükséglete lehet például egy hosszútávfutónak egy súlyemelôvel szemben. Nincs azonban két egyforma ember, eltérö az egyének genetikai adottsága, testsúlya, testösszetétele, mozgásintenzitása, az anyagcseréje és a cél amit el szeretnének érni, éppen ezért az egyes sportágakon belül az egyénre szabott étrend-összeállítás eredményezi a legjobb teljesítményt. Tanulmányunkban célul túztük ki az említett szempontok alapján a különböző összetételü étrendek, diéták hatásának elemzését a sportteljesítményre. Munkák során a Google és Pubmed oldalakon gyüjtöttünk, tekintettünk át releváns tartalmakat. Összességében azt mondhatjuk, hogy a helyes táplálkozás kialakítása sokszorosan megtérülő befektetés lehet. A sport, mint fizikai aktivitás meghatározza az életmódot, beleértve a táplálkozást is. A helyes, kiegyensúlyozott táplálékbevitel mind a sportolók, mind a nem sportolók számára elengedhetetlen.

Kulcsszavak: étrend, táplálék, tápanyag, mozgás

\section{Abstract}

The fuel of the human body is food, more specifically the nutrients it contains, so even non-athletes need to pay close attention to what they eat. It is even more important for athletes to develop performance-optimizing eating habits. Sport nutrition is one of the biggest opportunities for performance optimization that has become more and more important recently. There are many special diets, perhaps the best known are: ketogenic diet, Mediterranean diet, vegetarianism, paleo diet. We need to choose our diet while maintaining good health. We should not forget that a longdistance runner, for example, may need a completely different diet than a weightlifter. However, no two people are the same, individuals have different genetics, weight, body composition, movement intensity, metabolism, and the goal they want to achieve, which is why an individualized diet combination within each sport results in the best performance. In our study, we aimed to analyze the effect of diets of different compositions on sports performance based on the mentioned aspects. In the course of our work, we collected and reviewed relevant content on Google and Pubmed. Overall, it can be said that developing the right diet can be a multiplier return on investment. Sport 
as a physical activity determines lifestyle, including nutrition. Proper, balanced nutrition is essential for both athletes and non-athletes.

Keywords: diet, food, nutrition, exercise

\section{ELMÉLETI HÁTTÉR}

A diéta magyarul étrendet jelent, ami lehet általános étrend vagy specializált forma, a közbeszédben alacsonykalóriás fogyókúrás étrenddel vagy emésztőszervi megbetegedések során tartandó zsírszegény étrenddel kapcsolatban használatos [I01]. A különböző diétákat számos szempont szerint lehet csoportosítani (1. ábra):

- az egyén életkora szerint ajánlatos étrend (növekedésben lévő gyerekek és idősek magas esszenciális aminosav tartalmú diétája)

- speciális élethelyzetek által megkövetelt diéták (pl. terhességben magas B9 és B12 vitamin bevitel)

- rövid diéták (pl. székrekedés esetén magas növényi rosttartalmú étrend)

- preventív diéták (pl. magas omega-3 zsírsavtartalmú, „eszkimó” diéta a szív- és érrendszeri betegségek elkerülése érdekében)

- betegségek tüneteit enyhítő hosszú távú diéták (pl. tejcukormentes étrend laktózintoleranciában vagy alacsony fehérjetartalmú étrend veseelégtelenség esetén)

- különleges tápanyagigények esetén (pl. alacsony szénhidráttartalmú étrend cukorbetegekben)

A különböző étrendeket lehet csoportosítani a kalória és tápanyagtartalmuk szerint is:

- Alacsony energiatartalmú étrend ajánlatos fogyókúra idején

- Energiában gazdag diéta ajánlott tömegnövelő edzésekhez például

- Fehérjeszegény étrend vesebetegeknek

- Magas biológiai értékű fehérjében gazdag étrend növekedésben lévőknek illetve időseknek

- Komplex szénhidrátokban gazdag étrend egyes májbetegségekben

- Szénhidrát szegény étrend cukorbetegségben

- Zsírszegény étrend az érelmeszesedés kockázatának csökkentése érdekében

- Zsírokban gazdag és szénhidrátszegény (ketogén) étrend

- Nátrium-szegény étrend magas vérnyomás esetén 


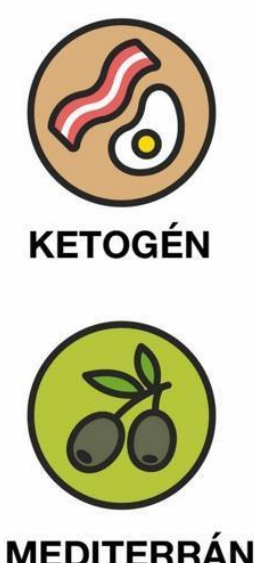

\section{MEDITERRÁN}

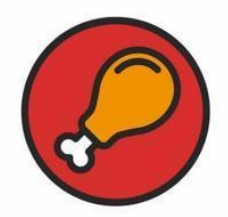

PALEO

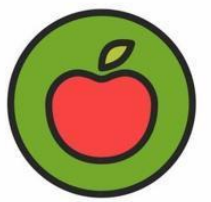

NYERS VEGÁN

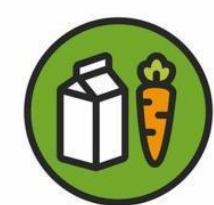

VEGETÁRIÁNUS

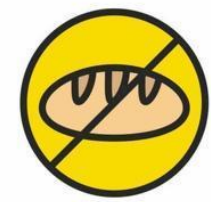

ALACSONY

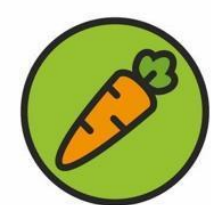

VEGÁN

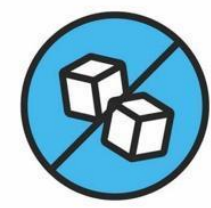

CUKORMENTES

1. ábra: Különböző típusú diéták

Forrás: Módosítva https://www.forksoverknives.com alapján

Akármelyik csoportosítást is vesszük alapul, a diéta célja a szervezet megváltozott állapotához vagy egy adott célhoz igazodó táplálkozás.

A mitokondriumok a sejtek energiatermelő központjai. Részt vesznek az esszenciális metabolikus és katabolikus folyamatokban, szerepük van a kalcium homeosztázis szabályozásában, a redox egyensúlyban és az apoptózisban is. Oxigén jelenlétében a sejtek energiájának döntő hányada aerob glikolízisből származik, melynek során a glükóz piruváttá metabolizálódik. A folyamatot oxidatív foszforiláció követi a mitokondriumokban. Glükóz hiányában az energia zsírsavak és a fehérjék lebontásából ered. A májban az alacsony plazma glükóz szint esetében elindul glükoneogenezis és ennek következtében a zsírsavak lebontása (béta-oxidáció) során keletkező acetil-CoAból ketontestek (3- $\beta$-hidroxi-butirát, acetoacetát, aceton) képződnek (2. ábra). Ez gyakran előfordul éhezés vagy hosszan tartó testmozgás során, amikor a glükóz ellátás elégtelen (KREBS, 1960; MITCHELL et al., 1995). 


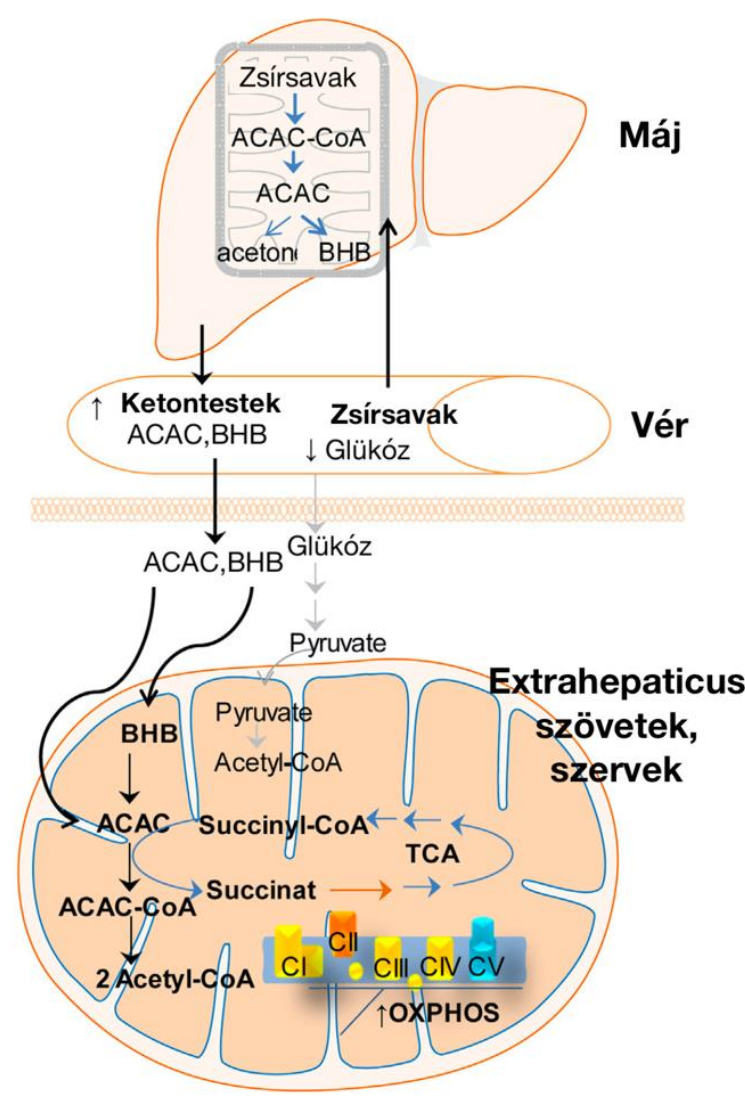

2. ábra: A ketontestek: acetoacetát (ACAC), $\beta$-hidroxi-butirát (BHB) és az aceton elsősorban a májsejtek mitokondriális mátrixában termelődnek zsírsavak oxidációja során. Az ACAC és a BHB extrahepatikus szövetekbe exportálódik, ahol acetil-CoA-vá alakul. Az acetil-CoA a citromsav-ciklusba (TCA) kerül, hogy az OXPHOS-on (oxidatív foszforiláció) keresztül ATP-t termeljen. A ketogén diéta a zsírsav-oxidáció serkentéséhez, egyidejüleg alacsonyabb vércukorszinthez vezet. Rövidítések:ACAC-CoA: acetoacetil-CoA, CI: I komplex, CII: II komplex, CIII: III komplex, CIV: IV komplex, CV: V. komplex Forrás: Módosítva www.elsevier.com/locate/biocel alapján

Mivel az egészséges máj a glükoneogenezis során képes előállítani a szervezet számára összes glükózt (az ember számára nincs esszenciális szénhidrát) ezért a szénhidrátok bevitele, különösen a finomított cukroké, csökkenthető az étrendben. A ketogén étrend (KD) magas zsírtartalmú, alacsony szénhidrát tartalmú étrend, amelynek metabolikus következményei tulajdonképpen megegyeznek a hosszú távú éhezésével. A keton testeket főleg a májsejtek mitokondriális mátrixában keletkeznek ketogenezis során, majd a véráramon keresztül más szervekbe transzportálódnak a test energiaigényének kielégítése céljából (2. ábra). A ketogén dezaminált aminosavak, mint például a leucin szintén ketontestek képződését eredményezik a citromsav ciklus táplálásán keresztül (SILVIA et al., 2015). A ketogén diétának számos pozitív hatása ismert mind az agyszövet, mind a zsírszövet, mind az izomszövet vonatkozásában (3. ábra). 


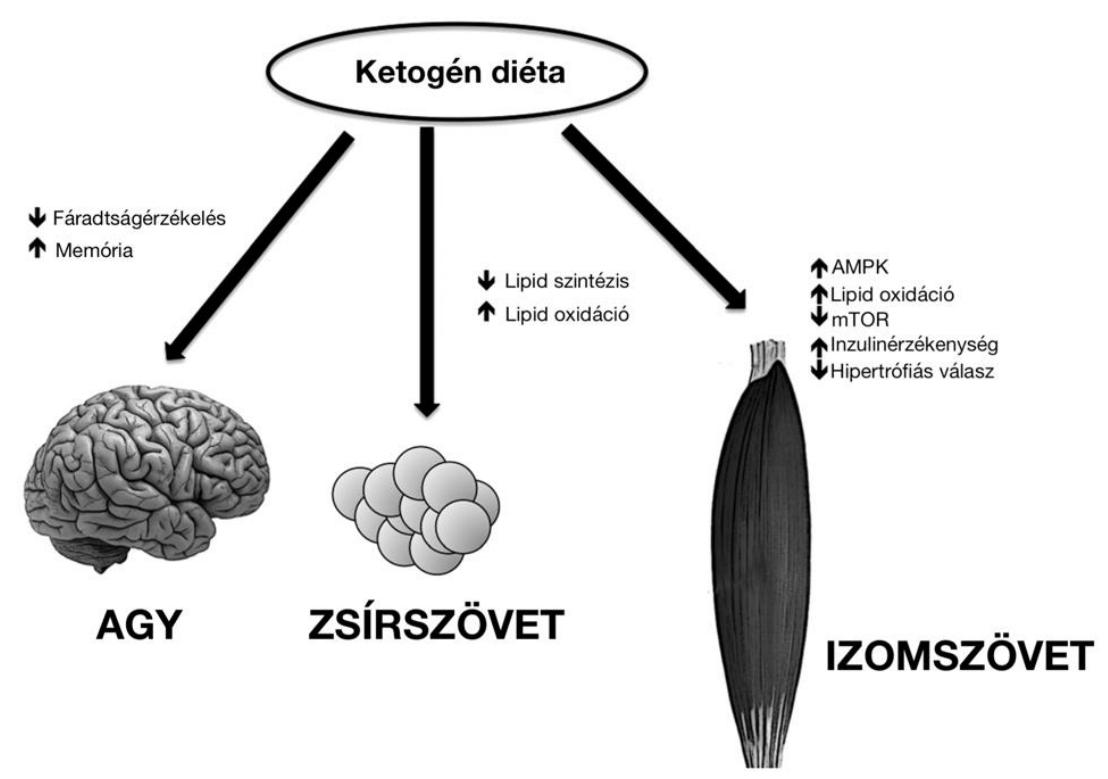

3. ábra: A ketogén diéta agyra, zsírszövetre, izomszövetre kifejtett hatásai

AMPK: 5'adenosine monophosphate-activated protein kinase; mTOR: mammalian target of rapamycin Forrás: Módosítva https://pubmed.ncbi.nlm.nih.gov/25906427/alapján

A vegetáriánus a „vegetarian” angol szóból ered, a vegetable (zöldség) + arian szóösszetétel eredménye. A vegetáriánusok nem fogyasztanak húst és húsból készült melléktermékeket (pl.: állati kötőszövetből készült zselatint). A vegán/veganizmus egy olyan szemléletmód, mely az állatok szabad élethez való jogát-érdekeit kívánja tiszteletben tartani és globálisan érvényesíteni [I02]. A vegetáriánus étrendre vonatkozó tudományos adatok a mai napig nem teljesen egyhangúak. Nincs egy homogén vegetáriánus csoport, sokféle ember eszik többnyire/kizárólag növényi eredetű ételeket. A vegetáriánus étrend együtt jár a növényi eredetű táplálékok magasabb arányú fogyasztásával. Ennek vitathatatlan előnye az állati eredetű élelmiszerekhez képest a magasabb arányú telítetlen zsírsav-, étkezési rost-, fitokemikália-, víztartalom (LEITZMANN, 2005). Ugyanakkor tömeg arányosan kevesebb magas biológiai értékű fehérjét és vasat tartalmaz, mint egy állati fehérjét is tartalmazó étrend (CAMPBELL, 2019).

A mediterrán étrend gazdag halakban, telítetlen zsírokban, teljes kiőrlésű gabonákban, gyümölcsökben, zöldségekben, diófélékben és hüvelyesekben. Meta-analízisek, kohorsz-, randomizált és kontrollált vizsgálatok alapján kimutatták, hogy az ilyen étrend csökkenti a szív- és érrendszeri morbiditást és a mortalitást. A halak szív- és érrendszeri betegségekre gyakorolt jótékony hatásának hátterében a jobb lipidprofil és a vérnyomáscsökkentő tulajdonságuk áll, feltehetően gyulladáscsökkentő, oxidatív folyamatok révén. (WIDMER et al., 2015). 
A paleolit vagy „paleo” étrend elnevezés az őslakos vadászó-gyűjtögető populációk kiváló kardiometabolikus egészségi állapotából és fizikai erőnlétéből fakad (HILLS et al., 2018). A paleo étrendet az egész világon népszerűsítik, mint az emberi egészség javításának és a különféle kockázati tényezők miatt terjedő betegségek csökkentésének egyik legjobb módját (SACHDEV et al., 2018). A paleo diétát követőknek tartózkodniuk kell a keményítőtől (burgonya, kukorica, finomított szénhidrátok), az összes gabonafélétől (tészta, rizs, kenyér, liszt, árpa), az előre csomagolt, fagyasztott ételektől, a hozzáadott cukroktól és a tejtermékektől. Maroknyi adag állati fehérje fogyasztása viszont reggelire, ebédre és vacsorára is ajánlott a teltség elérése érdekében [I03].

\section{MÓDSZER}

\section{ADATGYÜJTÉS}

Munkánk során a Google és Pubmed (https://www.ncbi.nlm.nih.gov/pubmed/) oldalakon gyűjtöttünk különböző diétákkal, étrendekkel kapcsolatos cikkeket. Igyekeztünk a sportteljesítményre kifejtett hatásokra fókuszálni.

\section{EREDMÉNYEK}

\section{KETOGÉN DIÉTA ÉS A SPORT}

Annak ellenére, hogy továbbra is sok kétség merül fel a KD sportban való alkalmazásával kapcsolatban, néhány eredmény kiemeli annak szükségességét, hogy megértsük a diéta sportolásra kifejtett hatását. Előző kutatások alapján a súlyvesztésre, neurológiai betegségekre és általánosságban véve az egészséggel kapcsolatos állapotokra is hatással lehet a ketogén diéta. Ez egy olyan étrendtípus, amelynek számos előnye van a szélsőséges, korlátozott energiájú „összeomlás” diéták egyéb típusai hoz képest. Ez utóbbi, még csak néhány napig is alkalmazva, az alapvető tápanyagok hiányát okozhatja (vitaminok, ásványi anyagok, esszenciális zsírsavak és aminosavak), valamint megfosztja a testet az egyéb makro tápanyagoktól, amelyek segítenének az oxidatív stressz és a gyulladásos folyamatok szabályozásában. Az elegendő energiát biztosító KD étrend megfelelő mennyiségű fehérjével (minimum 1,3-1,5g / ttkg) nem „extrém” diéta, eltekintve a nagyon alacsony szénhidrátszinttől (<20 g szénhidrát / nap), viszont nem vezet anyagcsere-egyensúlytalansághoz, amelynek visszafordíthatatlan hatása lehetne (PAOLI et al., 2015). A KD befolyásolja a kitartást, a súlyvesztést és az erő/energia paramétert a különböző típusú sportok esetében (4. ábra).

Érdemes ugyanakkor figyelembe venni, hogy a magas fehérjebevitel nagymértékű aminosav lebontást generál, ami nagy mennyiségű savtermelésen keresztül fokozott 
megterhelést okoz a veséknek ezért vesebetegeknek nem ajánlott a magas fehérjebevitelű ketogén diéta (CUENCA et al., 2015).

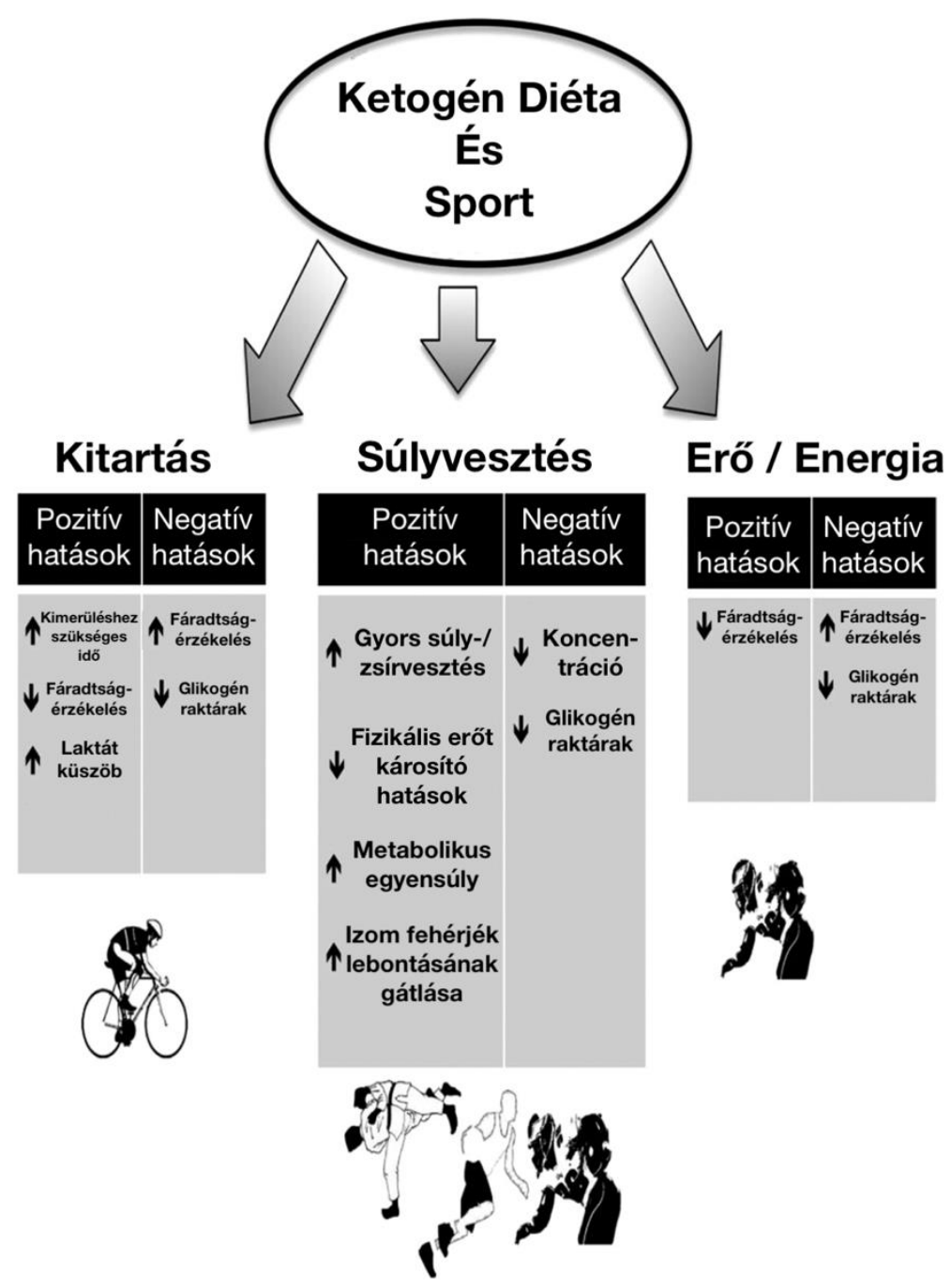

4. ábra: A ketogén diéta hatásai a különböző sportokban, azok lehetséges fiziológiai mechanizmusai Forrás: Módosítva https://pubmed.ncbi.nlm.nih.gov/25906427/alapján

\section{MEDITERRÁN DIÉTA ÉS SPORT}

Dr. Edward Weiss,az SLU táplálkozási és dietetikus professzora szerint a mediterrán étrend számos egészségügyi előnnyel bír. Kutatócsoportjával a mediterrán étrend gyulladáscsökkentő és antioxidáns hatását vizsgálták és azt találták, hogy a lúgosabb pHértékkel bíró ételek és a magasabb nitrát tartalom javítják a mozgásteljesítményt [I04].

„A mediterrán ételek összetevői (5. ábra) azonnal vagy néhány napon belül javítják a sportteljesítményt." - mondta Weiss. "Ezek az előnyök azonban nagyon gyorsan elmúltak 
nyugati étrendre való áttérést követően, kiemelve a mediterrán étrend hosszú távú betartásának fontosságát [I04]."

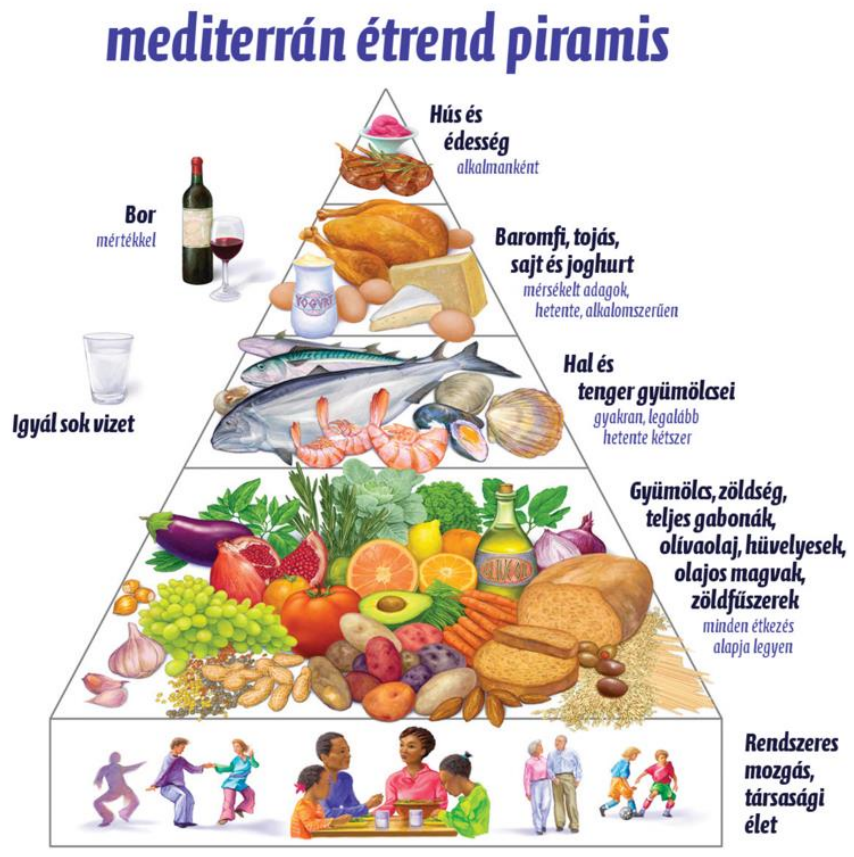

5. ábra: A mediterrán étrend piramis

Forrás: https://www.frissfood.hu/hirek/mediterran-dieta-a-frissfood-kinalataban

Weiss Professzor elmondása szerint a tanulmány 6 százalékkal jobb futási időt mért 5 kilométer távolságon a mediterrán étrendet követők körében a nyugati étrenden levőkhöz képest hasonló fizikai erőkifejtés és pulzusszámok mellett [I04].

\section{VEGETÁRIÁNUS/VEGÁN DIÉTA ÉS A SPORT}

Az elmúlt években tapasztalt teljesítménybeli problémákkal, alultápláltsággal kapcsolatos viták ellenére a vegán vagy vegetáriánus sportolók által elért egyre jobb eredmények miatt a növényi alapú étrend nagy figyelmet élvez [I05].

Felmerül a kérdés, hogy összeegyezethető-e a vegetáriánus/vegán étrend a sportolók, különösen az állóképességi sportolók energia- és tápanyagigényével, illetve hozzá tud-e járulni a teljesítmény fenntartásához esetleg javításához. Ezekre a kérdésekre nincs egyértelmű válasz, de néhány alapvető vélemény tény már kialakult a tudományos társadalomban. Az Amerikai Dietetikus Szövetség támogatja a jól megtervezett, tejet és tojást tartalmazó vegetáriánus vagy teljes vegán étrendet (6. ábra) és úgy tartja, hogy az egészséges, táplálkozási szempontból megfelelő és jó hatással lehetnek egyes betegségek ellen is [105]. 


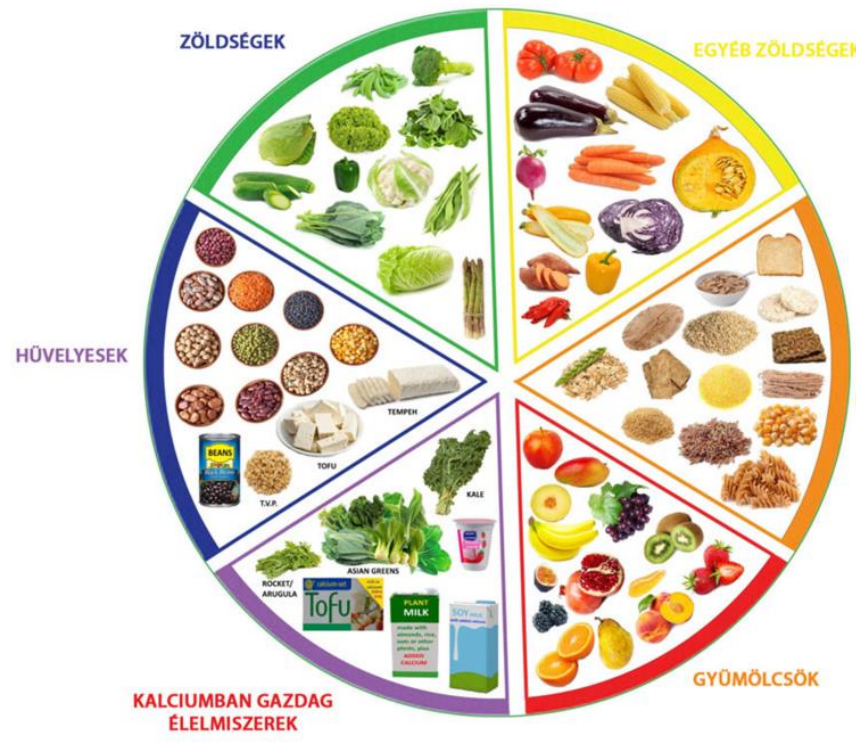

6. ábra: A vegán/vegetáriánus étrendet képző föbb táplálékok

Forrás: https://www.bulkshop.hu/vegannak-lenni-es-a-vegan-etrend-elonyei

A sportteljesítményt illetőleg, az American College of Sports Medicine nem tesz különbséget a vegetáriánus vagy vegán sportolók táplálkozási szükségleteit a mindenevőkétől. Fontos azonban figyelembe venni a jól ismert tényt, hogy a növényi eredetű fehérjék az emésztés során nehezebben hozzáférhetők a növényi sejtfal miatt illetve a növények kisebb mennyiségben tartalmaznak D vitamint, a riboflavint (B2 vitamin), kobalamint (B12 vitamin), vasat, kalciumot és cinket, mint az állati eredetű táplálék. Mind növényi, mind pedig állati forrásokból hozzájuthatunk a szükséges mennyiségű fehérjéhez viszont a növényi alapú fehérjék felszívódása kisebb hatásfokkal zajlik, mint az állati fehérjéké és a növényi fehérjék biológia értéke (ami korrelál az esszenciális aminosav-tartalommal) szintén kisebb az állati eredetű fehérjékkel összehasonlítva. Ezeket figyelembe véve egy vegán/vegetáriánus életmódot folytató sportolónak célszerűbb 10\%-al több fehérjét fogyasztani. Szükség esetén esszenciális aminosavak, vitaminok, nyomelemek bevitele is szükségessé válhat étrend-kiegészítők formájában [105].

\section{PALEO DIÉTA ÉS A SPORT}

A paleo diétával kapcsolatos tanulmányok többsége a kiemelkedő állóképességet igénylő sportokat boncolja. Az ezt űzők nagymértékben támaszkodnak mind az anaerob, mind az aerob energiatermelésre, de hajlamosak megfeledkezni az optimális fehérjebevitel hangsúlyozásáról. A paleo diéta (7. ábra) gazdag sovány húsokban (hal, kagyló, tojás), 
ennek eredményeként ösztönzi a magas fehérje tartalmú étrend betartását (BUJKO et al., 2014).

A sportolók étrendjének mikrotápanyag hiányai a fizikai teljesítmény csökkenéséhez vezethetnek. A tej és a teljes kiőrlésű gabonafélék átlagos tápanyag-sűrűsége (az amerikai étrendben gyakori) alacsonyabb, mint a zöldségeké és gyümölcsöké, sovány húsé és kagylóké, amelyek a paleo étrend alappillérei (BUJKO et al., 2014).

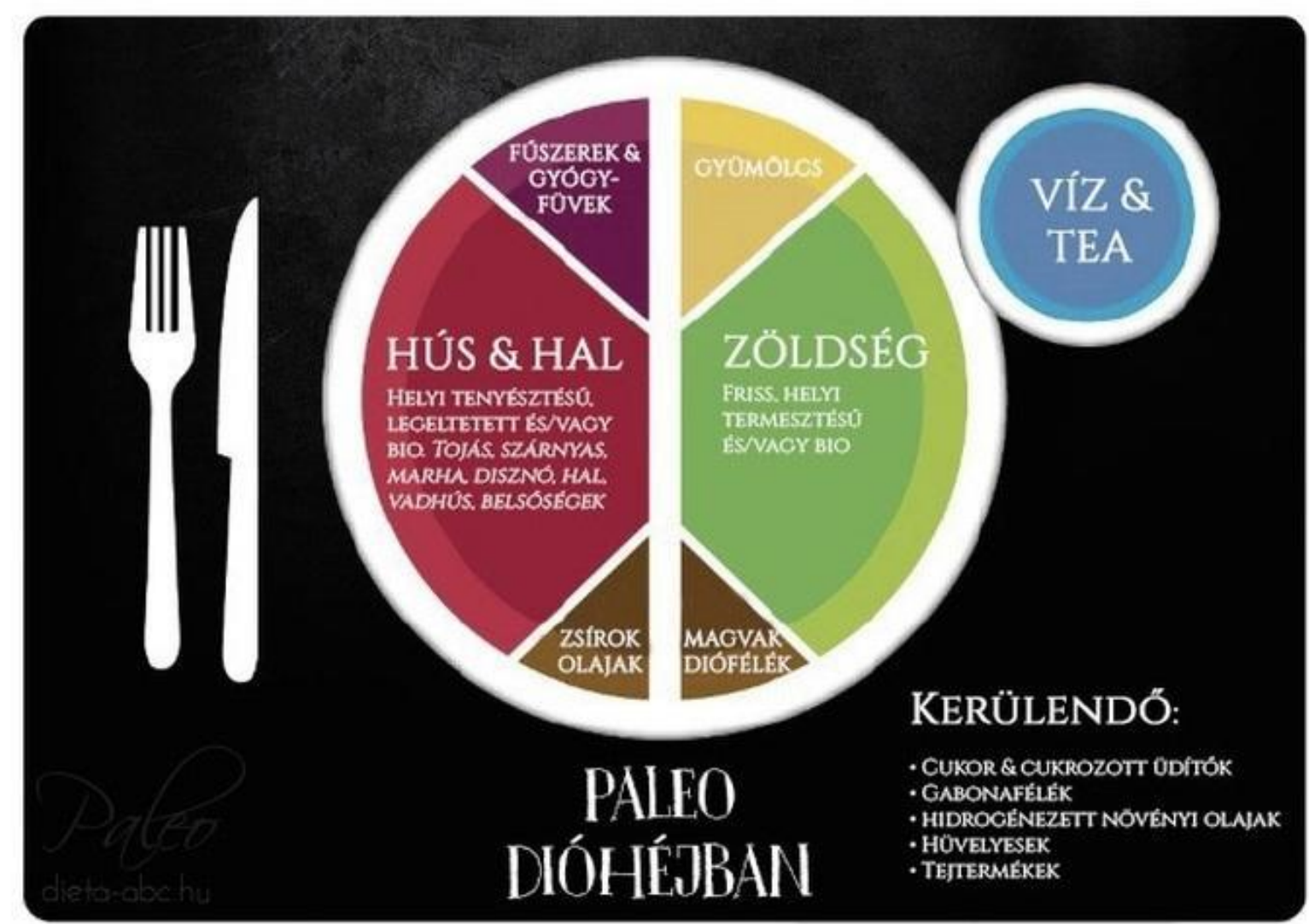

7. ábra: A paleo diéta dióhéjban

Forrás:

https://egeszsegguru.blog.hu/2017/04/30/a paleo etrend mit ehetsz miert jo es egy fincsi desszert recep $\underline{t}$

Amellett, hogy a paleo diéta kevesebb, minőségi szénhidrátot tartalmaz, a fogyasztó számára összetett-, és potenciálisan megfelelő szénhidrátbevitelt biztosít. A sportolónak azonban ügyelnie kell a szénhidrátfogyasztás időzítésére (CHALLA et al., 2019). 


\section{MEGBESZÉLÉS}

A KD sportban történő alkalmazása még mindig ködös zónát jelent, „középút a fény és az árnyék, tudomány és babona között”. Rendelkezésre áll néhány biztató adat, amely a KD különböző sportágakban betöltött hasznára utal, ezek közé tartoznak a különböző súlykategóriás sportok, az esztétikai, állóképességi sportok. Nagyon fontos, hogy az edzők, a sportorvosok és a dietetikusok is tisztában legyenek e táplálkozási stratégia erősségeivel és hátrányaival. Az állóképességi sportok kapcsán ismeretes néhány előzetes eredmény, amelyek arra utalnak, hogy a KD hasznos módszer lehet a zsíranyagcsere és az oxidáció javítására a teljesítmény fokozásán keresztül (4. ábra). Az áttekintett tanulmányok alapján azt gondoljuk, hogy a KD alkalmazása a sportban megérdemli és igényli is a további kutatást.

A rendszeres testmozgás elengedhetetlen alkotóeleme a mediterrán diétának. A jó közérzet kialakítása mellett a fizikai aktivitás elősegíti az ideális testsúly mielőbbi elérését, majd megtartását. A mediterrán diéta részeként lehetőleg minden nap, de legalább heti 2-3 alkalommal kb. fél órás testmozgást építsünk napirendünkbe. $\mathrm{Ne}$ feledkezzünk meg arról, hogy a mediterrán diéta nem alkalmas gyors fogyásra. A módszer lassú, viszont annál biztosabb eredményhez vezet. A minőségi élelmiszerek magasabb ára miatt ugyan nem olcsó a kivitelezése, de hosszú távon egyértelműen megéri [I06].

Egyre több sportoló számol be arról, hogy egy jól megtervezett és kiegyensúlyozott növényalapú étrend javítja az általános hangulatot, az egészségérzést, az edzés minőségét, a regeneráció hatásfokát és a teljesítményt. Szem előtt kell tartanunk azonban ezen életmód veszélyeit, az esetleges hiánybetegségek lehetőségét, szükség esetén célszerű lehet a hiányzó elemek pótlása étrend-kiegészítőkkel.

A paleo diéta nagyszerű megoldást kínál a fogyáshoz és a teljes tápanyag értékű étrend népszerūsítéséhez. Az alacsony szénhidrát tartalmú ételek előnyben részesítése és a magas szénhidrát tartalmú ételek mennyiségének minimalizálása alapján azonban a nagy erőkifejtést igénylő sportot űzők számára nehezebben betartható azonos teljesítmény elérése mellett.

Annak ellenére, hogy a tejfehérjék nem képezik a paleo diéta részét, gondos tervezéssel a fehérjeszükséglet kielégíthető sovány húsforrásokkal. A nagy erőkifejtést igénylő sportot űzők számára a versenyszezonon kívüli táplálkozási tervben lehet fontos szerepe. 
Munkánkat az Európai Unió projektje: Intézményi fejlesztések az intelligens szakosodási programhoz (pályázat száma: EFOP-3.6.1-16-2016-00022 „Debrecen Venture Catapult Program") támogatta.

\section{IRODALOMJEGYZÉK}

Bujko, J., \& Kowalski, Ł. M. (2014). The question of ergogenic potential of the Paleolithic diet. Trends in Sports Sciences, 21(4).

Campbell, W. W. (2019). Animal-based and plant-based protein-richfoods and cardiovascularhealth: a complexconundrum. The American Journal of ClinicalNutrition. doi:10.1093/ajcn/nqz074

Challa, H. J., \& Uppaluri, K. R. (2019, May 29). Paleolithic Diet. Nih.Gov; StatPearls Publishing.

Cuenca-Sánchez, M., Navas-Carrillo, D., \& Orenes-Piñero, E. (2015). Controversies Surrounding High-Protein Diet Intake: Satiating Effect and Kidney and Bone Health. Advances in Nutrition, 6(3), 260-266. doi:10.3945/an.114.007716

D Hills Jr, R., \& Erpenbeck, E. (2018). Guide to popular diets, food choices, and their health outcome. Health Care : Current Reviews, 06(02). https://doi.org/10.4172/2375$\underline{4273.1000223}$

Krebs H. (1960). Biochemical aspects of ketosis. Proc R Soc Med, 53:71-80.

Leitzmann, C. (2005). VegetarianDiets: WhatAretheAdvantages? DietDiversification and Health Promotion, 147-156. doi:10.1159/000083787

Mitchell GA, Kassovska-Bratinova S, Boukaftane Y, Robert MF, Wang SP, \& Ashma- Rina L, et al. (1995). Medicalaspects of ketone body metabolism. Clin Invest Med, 18:193-216.

Paoli, A., \& Bianco, K. A. (2015). The KetogenicDiet and Sport. Exercise and Sport SciencesReviews, 43(3), 153-162. doi:10.1249/jes.0000000000000050

Sachdev, N. V. V. P., \& Rengasamy, G. (2018). Paleo Diet - A Review. International Journal of Research in Pharmaceutical Sciences, 9(2). 
Silvia V, Sepideh A, Bridget L, Tricia R, Wolfgang S, Barbara K, \& René G.F. (2015). Mitochondria: The ketogenicdiet-A metabolism-basedtherapy. The International Journal of Biochemistry\&CellBiology 63, 55-59.

Widmer, R. J., Flammer, A. J., Lerman, L. O., \& Lerman, A. (2015). The MediterraneanDiet, itsComponents, and CardiovascularDisease. The American Journal of Medicine, 128(3), 229-238. doi:10.1016/j.amjmed.2014.10.014

\section{Internetes hivatkozások:}

I01: https://hu.wikipedia.org/wiki/Diéta (étrend)

I02: https://prove.hu/mi-a-kulonbseg-a-vegetarianus-es-a-vegan-kozott/

I03: https://blog.nasm.org/paleo-diet-for-strength-power-

athletes? fbclid=IwAR3N9IJVt-

7f9XxwgcVlWzMqAkiEyQ9nyZ6gRcj7ZnBAXszqlR8CBxUcvCI

I04: https://www.slu.edu/news/2019/march/mediterranean-diet-boosts-endurance-

exercise.php

I05: https://www.simplesport.hu/vegan-etrend-es-a-sport/

I06: https://www.vital.hu/mediterran dieta 